\title{
Turnover Intention among Public Sector Health Workforce: Is Job Satisfaction the Issue?
}

\author{
Roslan JMGa , Noor Hazilah AM ${ }^{b}$, Nor Filzatun Bc , Azahadi MO \\ ${ }^{a}$ Cheras Rehabilitative Hospital, 56000 Kuala Lumpur \\ 'Department of Business Administration, International Islamic University Malaysia \\ 'Institute of Health Management, Ministry of Health Malaysia \\ Institute of Public Health, National Institute of Health, Ministry of Health Malaysia
}

\begin{abstract}
Introduction: Introduction: The paper explores turnover intention and job satisfaction among healthcare employees of Ministry of Health $(\mathrm{MOH})$ Malaysia. Methods: A nationwide study was carried out in order to identify dimensions of job satisfaction and turnover intention among public healthcare employees. Data was collected by means of self-administered questionnaire and distributed based on quota sampling. Results: The study shows that public healthcare workforce is generally satisfied with their work (mean 3.45). In addition, medical specialists and assistant medical officers were found to be significantly more satisfied than other job designations. However, intention to resign was high among medical specialists, pharmacists and dentists. A high proportion of medical specialists also had received job offers from the private sector. Conclusion: The findings showed that employee turnover may not necessarily be due to job dissatisfaction, but rather due to demand from the private sector. Findings from the study would assist policy-makers with respect to talent management in public healthcare service.
\end{abstract}

KEYWORDS: Human resource, healthcare management, Malaysia, employee turnover, job satisfaction.

\section{INTRODUCTION}

Employee turnover is a cause of concern for healthcare organisations as it bears implications on the quality of service provided to patients. Employee turnover refers to the process of employees leaving an organisation and having to be replaced. ${ }^{1}$ High employee turnover results in increased costs in selection and recruitment; and orientation and training. It also affects organisational productivity as well as morale and motivation of remaining employees. Employee turnover is often found to be negatively correlated with job satisfaction. ${ }^{2,3,4,5}$

Job satisfaction, on the other hand, has been defined by Locke $^{6}$ as a pleasurable or positive emotional state resulting from the appraisal of one's job or job experiences. Thus, it reflects an employee's general attitude toward, and his feeling about, his job. According to Stamps and Slaritt ${ }^{7}$ domains of job satisfaction among health professionals include variables such as pay, autonomy, task requirement, organizational requirements, interaction and job

\section{Corresponding author:}

Assoc. Prof. Dr. Noor Hazilah Abd. Manaf Department of Business Administration Kulliyyah of Economics and Management Sciences International Islamic University Malaysia P.O.Box 10, 50728 Kuala Lumpur

Email: hazilah@iium.edu.my prestige. Rad and Moraes, ${ }^{8}$ however, found dimensions of job satisfaction among employees in public hospitals to be pay, promotion, supervision, fringe benefits, contingent rewards, working conditions, co-workers, nature of work, and communication.

According to Manaf, ${ }^{9}$ the Malaysian public healthcare is at a crossroad. The changing socio-economic development of the country, escalating healthcare costs, rising patient expectations, changing demography and epidemiology, all have implications on the nations' public healthcare system; and consequently, its health workforce. Thus, staff retention is also an imperative in Malaysian public healthcare service, which often always has to compete for talent with the more lucrative private sector. Van Dam ${ }^{10}$ posited that intention to leave an organisation is also affected by alternatives that are available in the market.

This study attempts to explore the level of job satisfaction and turnover intention among healthcare employees of the Ministry of Health Malaysia. Dimensions of job satisfaction will be explored, and the relation between this construct and turnover intention will also be investigated. 


\section{MATERIALS AND METHODS}

Across-sectional study was conducted with respondents from various job designations at the Ministry of Health $(\mathrm{MOH})$. Data was collected through a self-administered questionnaire, which consisted 31 items relating to job satisfaction based on five-point Likert scale ranging from 1 (strongly disagree) to 5 (strongly agree). Items on turnover intention such as intention to resign, and job offers from the private sector were also posed to the respondents. The instrument was pilot tested to a sample of thirty respondents and feedback from the respondents was incorporated into the final instrument.

All MOH facilities comprising hospitals, clinics, health offices, and laboratories participated in this nationwide study. Sampling size was calculated by the estimated prevalence of $50 \%$ precision of 0.05 with non-respondent of $20 \%$ and the design effect of 2. A total of 16,340 questionnaires were distributed throughout the country, including Sabah and Sarawak. Of these, 10,457 responses were received, which gave a response rate of $64 \%$. Data analysis was carried out by using SPSS version 15.0. Data was subjected to reliability analysis and dimensions of job satisfaction were extracted from factor analysis by Varimax rotation.

\section{RESULTS}

Sociodemographic and Work Characteristics

Table 1. Factor loadings of job satisfaction items
The total number of respondents was 10,457 (out of $16,340)$ which gave a response rate of $64.0 \%$. The majority of respondents were female $(68.7 \%)$. Forty two per cent of the respondents were from the age group of 27 to 36 years, followed by those who are less than 26 years old $(20.6 \%)$. Those who are between 37 to 46 years old made up $18.9 \%$ of the respondents, while the remaining $18 \%$ were those are more than 47 years old. The Paramedic and Auxiliary group of employees also formed the majority of respondents at $76.4 \%$, while the Professional and Management group was $30.5 \%$. Employees who have also served the $\mathrm{MOH}$ for more than ten years made up $36.3 \%$ of the respondents followed by $29.8 \%$ for those who have served between 4 to 10 years; $33.6 \%$ between 1 to 3 years; and only $0.2 \%$ have served less than a year. Malays made up the largest majority at $74.7 \%$, followed by Chinese (10.2\%), Indians (6.4\%) and 'others' at $9.2 \%$.

\section{Reliability and Validity}

Reliability analysis by using Cronbach's coefficient alpha was carried out on 31 items relating to job satisfaction. The Cronbach's alpha, at 0.78 was found to exceed the acceptable level proposed by Nunnally. ${ }^{11}$ Extraction for factor analysis was done by principal component analysis and Varimax rotation, with the minimum acceptable level of significance of 0.30 for factor loading. ${ }^{12}$ Factor analysis grouped the items into eight factors, which accounted for $56.42 \%$ of total variance, as shown in Table 1.

\begin{tabular}{|c|c|c|}
\hline Factor & Items & Factor Loading \\
\hline \multirow[t]{3}{*}{1} & $\begin{array}{l}\text { I have many opportunities to attend training programmes organized by my } \\
\text { department }\end{array}$ & 0.77 \\
\hline & $\begin{array}{l}\text { I have many opportunities to attend training programmes organized by other } \\
\text { agencies }\end{array}$ & 0.77 \\
\hline & In my department, the participants for training/courses are fairly selected & 0.61 \\
\hline \multirow[t]{3}{*}{2} & My current placement (work location) is my own choice & 0.87 \\
\hline & I was given the opportunity to choose my workplace & 0.85 \\
\hline & My current placement (work location) is appropriate with my skill & 0.56 \\
\hline \multirow[t]{4}{*}{3} & My colleagues provide quality services to the customers & 0.75 \\
\hline & I receive good cooperation from my colleagues & 0.65 \\
\hline & $\begin{array}{l}\text { For staff who is going to retire, their skills are still needed by my organization } \\
\text { My work environment is safe }\end{array}$ & 0.57 \\
\hline & I have heavy workload & 0.42 \\
\hline \multirow[t]{4}{*}{4} & I experience severe stress at my workplace & 0.80 \\
\hline & I cannot attend any training/courses because of my service priorities & 0.74 \\
\hline & I have not received any recognition after completing a training/course & 0.59 \\
\hline & The training that I had attended are effective in enhancing my skills in carrying & 0.43 \\
\hline \multirow[t]{3}{*}{5} & out my duty & 0.83 \\
\hline & The training provided are appropriate with my job specifications & 0.83 \\
\hline & The Performance Appraisal System should be used in promotion exercise. & 0.84 \\
\hline \multirow[t]{4}{*}{6} & The Performance appraisal System is practical (fair) and sensible. & 0.68 \\
\hline & Promotion exercise should be based on staff competency & 0.46 \\
\hline & Generally, the pay system for staff is equivalent with their work. & 0.36 \\
\hline & I am interested to further my studies & 0.79 \\
\hline \multirow[t]{2}{*}{7} & I am competent in using computer & 0.63 \\
\hline & I have the opportunity to further my studies & 0.57 \\
\hline \multirow[t]{3}{*}{8} & $\begin{array}{l}\text { In my opinion, when staff gets promoted, they will be placed in the } \\
\text { department that do not match with their skills }\end{array}$ & 0.72 \\
\hline & $\begin{array}{l}\text { At my workplace, there are many staff who exhibit misconduct behaviour } \\
\text { while working. }\end{array}$ & 0.65 \\
\hline & The promotion exercise is only based on seniority/longer duration of service. & 0.35 \\
\hline
\end{tabular}




\section{Dimensions of Job Satisfaction}

Factors extracted from job satisfaction items, as shown in Table 2, were subsequently labelled as opportunities for training (mean 2.98); right job and right place (mean 3.49); cooperation of colleagues (mean 3.73); workload and poor recognition (mean 3.03); effectiveness of training received (mean 4.00); performance appraisal and remuneration (mean 3.65); career development (mean 3.57) and promotion and service issues (mean 3.13). Opportunities for training has the lowest mean score at 2.98, while effectiveness of training received has the highest mean score at 4.00. All the items were summated to form a single variable for overall job satisfaction, which has a mean score of 3.45. This indicates that there is a good level of job satisfaction among $\mathrm{MOH}$ employees.

Table 2. Mean of dimensions of job satisfaction

\begin{tabular}{|c|c|c|c|c|}
\hline & N & Mean & Std. Deviation & $\mathrm{p}$-value \\
\hline Opportunities for training & 10457 & 2.98 & 0.89 & 0.00 \\
\hline Right job right place & 10457 & 3.49 & 0.98 & 0.00 \\
\hline Cooperation of colleagues & 10457 & 3.73 & 0.64 & 0.00 \\
\hline Workload and poor recognition & 10457 & 3.03 & 0.78 & 0.00 \\
\hline Effectiveness of training received & 10457 & 4.00 & 0.82 & 0.00 \\
\hline Performance appraisal and remuneration & 10457 & 3.65 & 0.70 & 0.00 \\
\hline Career development & 10457 & 3.57 & 0.79 & 0.00 \\
\hline Promotion and service & 10457 & 3.13 & 0.78 & 0.00 \\
\hline Overall job satisfaction & 10457 & 3.45 & 0.41 & 0.00 \\
\hline
\end{tabular}

Turnover Intention

Table 3 shows that almost $78 \%$ of the respondents had no intention to resign before reaching pensionable age, while $22 \%$ indicated their intention to do so. The medical officers had the highest rate of turnover intention (40.6\%); followed by dentists (39.8\%); pharmacists (38.8 \%); medical specialists (36.3\%) and tutors (33.9\%). A sizeable portion of physiotherapists also indicated their intention to resign at $22.1 \%$ of response. Turnover intention is lower among the nurses at $18.5 \%$ in comparison to those mentioned above.

Table 3. Turnover intention

\begin{tabular}{lll}
\hline & \multicolumn{2}{l}{ Intention to resign from service prior to reaching pensionable age } \\
\cline { 2 - 3 } Job designations & Yes $(\%)$ & No $(\%)$ \\
\hline Dental Nurse & 17.0 & 83.0 \\
Medical Lab Technologist & 12.9 & 87.1 \\
Assistant Medical Officer & 17.5 & 82.5 \\
Dispenser & 14.7 & 85.3 \\
Radiographer & 17.0 & 83.0 \\
Physiotherapist & 22.1 & 77.9 \\
Medical Attendants & 9.1 & 90.9 \\
Medical Officer & 40.6 & 59.4 \\
Pharmacist & 38.8 & 61.2 \\
Dentist & 39.8 & 60.2 \\
Tutor & 33.9 & 66.1 \\
Medical Specialist & 36.3 & 63.7 \\
Community Nurse & 11.3 & 88.7 \\
Staff Nurse & 18.5 & 81.5 \\
\hline Total & 22.2 & 77.8 \\
\hline
\end{tabular}




\section{Job offer from private sector}

The respondents were also posed the question as to whether they have received job offers from the private sector. The data showed that $26.5 \%$ of the respondents said that they had received such job offers while 73.5 $\%$ said they did not. The data highlighted some critical points. Among the medical specialists, almost 70 \% (i.e. $68.6 \%$ ) said that they had received job offers from the private sector. This was followed by tutors $(52.4 \%)$; pharmacists (50.8\%); dentists (44.8\%); medical officers (43.0\%); physiotherapists (36.3\%); and radiographers (33.4\%). For assistant medical officers, $28.8 \%$ have received such offers, while for trained nurses, $18.4 \%$ have received job offers from the private sector. Other categories of employment were less significant such as medical attendants $7.4 \%$, dental nurse $4.1 \%$ and community nurse $6.2 \%$.

\section{Intention to resign and job offers}

Cross-tabulation between those with intention to resign and those who have received job offers from the private sector indicate that almost $40 \%$ (i.e. 39.2 $\%$ ) of those who have received job offers also have the intention to resign.

\section{Job satisfaction and job designation}

Analysis of variance (ANOVA) followed by post hoctest was carried out between job designations and overall job satisfaction. The finding indicates that there is significant difference between job satisfaction and the various job designations. Since the result was significant, post-hoc analysis by using GamesHowell test was then carried out. The post-hoc test showed significant difference between the major job designations as shown in Table 4.

Table 4. Games Howell post hoc test for job satisfaction and job designation

\begin{tabular}{|c|c|c|c|c|c|c|}
\hline \multirow{2}{*}{$\begin{array}{l}\text { (I) job } \\
\text { designation }\end{array}$} & \multirow{2}{*}{$\begin{array}{l}\text { (J) job } \\
\text { designation }\end{array}$} & \multirow{2}{*}{$\begin{array}{l}\text { Mean } \\
\text { Difference } \\
(\mathrm{I}-\mathrm{J})\end{array}$} & \multirow{2}{*}{ Std. Error } & \multirow{2}{*}{ Sig. } & \multicolumn{2}{|c|}{ 95\% Confidence Interval } \\
\hline & & & & & Lower Bound & $\begin{array}{l}\text { Up per } \\
\text { Bound }\end{array}$ \\
\hline Assistant Medical & Dental Nurse & $0.18^{*}$ & 0.02 & 0.00 & 0.13 & 0.24 \\
\hline \multirow[t]{11}{*}{ Officer } & $\begin{array}{l}\text { Medical Lab Tech- } \\
\text { nologist }\end{array}$ & $0.13^{*}$ & 0.02 & 0.00 & 0.08 & 0.19 \\
\hline & Dispenser & $0.17^{*}$ & 0.02 & 0.00 & 0.11 & 0.23 \\
\hline & Radiographer & $0.15^{*}$ & 0.02 & 0.00 & 0.08 & 0.21 \\
\hline & Physiotherapist & $0.09^{*}$ & 0.02 & 0.00 & 0.02 & 0.16 \\
\hline & Medical Attendants & $0.17^{*}$ & 0.02 & 0.00 & 0.11 & 0.24 \\
\hline & Medical Officer & $0.14^{*}$ & 0.02 & 0.00 & 0.08 & 0.20 \\
\hline & Pharmacist & $0.21^{*}$ & 0.02 & 0.00 & 0.15 & 0.28 \\
\hline & Dentist & $0.17^{*}$ & 0.02 & 0.00 & 0.11 & 0.23 \\
\hline & Tutor & $0.11^{*}$ & 0.02 & 0.00 & 0.04 & 0.18 \\
\hline & Community Nurse & $0.17^{*}$ & 0.02 & 0.00 & 0.11 & 0.23 \\
\hline & Staff Nurse & $0.17^{*}$ & 0.02 & 0.00 & 0.11 & 0.23 \\
\hline \multirow{4}{*}{$\begin{array}{l}\text { Medical } \\
\text { Officer }\end{array}$} & Assistant Medical & $-0.14^{*}$ & 0.02 & 0.00 & -0.20 & -0.08 \\
\hline & Officer & & & & & \\
\hline & Pharmacist & $0.07^{*}$ & 0.02 & 0.01 & 0.01 & 0.13 \\
\hline & Medical Specialist & $-0.14^{*}$ & 0.02 & 0.00 & -0.20 & -0.07 \\
\hline \multirow[t]{6}{*}{ Pharmacist } & $\begin{array}{l}\text { Medical Lab Tech- } \\
\text { nologist }\end{array}$ & $-0.08^{*}$ & 0.02 & 0.00 & -0.14 & -0.02 \\
\hline & $\begin{array}{l}\text { Assistant Medical } \\
\text { Officer }\end{array}$ & $-0.21^{*}$ & 0.02 & 0.00 & -0.28 & -0.15 \\
\hline & Physiotherapist & $-0.12^{*}$ & 0.02 & 0.00 & -0.10 & -0.05 \\
\hline & Medical Officer & $-0.07^{*}$ & 0.02 & 0.01 & -0.13 & -0.01 \\
\hline & Tutor & $-0.10^{*}$ & 0.02 & 0.00 & -0.18 & -0.03 \\
\hline & Medical Specialist & $-0.21^{*}$ & 0.02 & 0.00 & -0.28 & -0.14 \\
\hline \multirow[t]{4}{*}{ Dentist } & Assistant Medical & & & & & \\
\hline & Officer & $-0.17^{*}$ & 0.02 & 0.00 & -0.23 & -0.11 \\
\hline & Physiotherapist & $-0.08^{*}$ & 0.02 & 0.02 & -0.15 & -0.01 \\
\hline & Medical Specialist & $-0.16^{*}$ & 0.02 & 0.00 & -0.23 & -0.091 \\
\hline \multirow[t]{9}{*}{ Medical Specialist } & Dental Nurse & $0.18^{*}$ & 0.02 & 0.00 & 0.11 & 0.24 \\
\hline & $\begin{array}{l}\text { Medical Lab Tech- } \\
\text { nologist }\end{array}$ & $0.13^{*}$ & 0.02 & 0.00 & 0.06 & 0.19 \\
\hline & Dispenser & $0.16^{*}$ & 0.02 & 0.00 & 0.10 & 0.22 \\
\hline & Radiographer & $0.14^{*}$ & 0.02 & 0.00 & 0.07 & 0.21 \\
\hline & Physiotherapist & $0.08^{*}$ & 0.02 & 0.01 & 0.01 & 0.16 \\
\hline & Medical Attendants & $0.17^{*}$ & 0.02 & 0.00 & 0.10 & 0.24 \\
\hline & Medical Officer & $0.14^{*}$ & 0.02 & 0.00 & 0.07 & 0.20 \\
\hline & Pharmacist & $0.21^{*}$ & 0.02 & 0.00 & 0.14 & 0.28 \\
\hline & Dentist & $0.16^{*}$ & 0.02 & 0.00 & 0.09 & 0.23 \\
\hline
\end{tabular}




\begin{tabular}{|c|c|c|c|c|c|c|}
\hline \multirow[b]{2}{*}{$\begin{array}{l}\text { (I) job } \\
\text { designation }\end{array}$} & \multirow[b]{2}{*}{$\begin{array}{l}\text { (J) job } \\
\text { designation }\end{array}$} & \multirow[b]{2}{*}{$\begin{array}{l}\text { Mean } \\
\text { Difference } \\
(I-J)\end{array}$} & \multirow{2}{*}{ Std. Error } & \multirow{2}{*}{ Sig. } & \multicolumn{2}{|c|}{ 95\% Confidence Interval } \\
\hline & & & & & Lower Bound & $\begin{array}{l}\text { Up p e r } \\
\text { Bound }\end{array}$ \\
\hline \multirow{4}{*}{$\begin{array}{l}\text { Me d i c a l } \\
\text { Specialist }\end{array}$} & Tutor & $0.10^{*}$ & 0.02 & 0.00 & 0.03 & 0.18 \\
\hline & Community & $0.17^{*}$ & 0.02 & 0.00 & 0.10 & 0.23 \\
\hline & Nurse & $0.16^{*}$ & 0.02 & 0.00 & 0.10 & 0.23 \\
\hline & Staff Nurse & $-0.17^{*}$ & 0.02 & 0.00 & -0.23 & -0.11 \\
\hline \multirow[t]{5}{*}{ Staff Nurse } & Assistant & $-0.08^{*}$ & 0.02 & 0.01 & -0.15 & -0.01 \\
\hline & $\begin{array}{l}\text { Medical } \\
\text { Officer }\end{array}$ & & & & & \\
\hline & Physiotherapist & $-0.16^{*}$ & 0.02 & 0.00 & -0.23 & -0.10 \\
\hline & Medical & & & & & \\
\hline & Specialist & & & & & \\
\hline
\end{tabular}

*The mean difference is significant at the 0.05 level. The findings indicate that among employees of $\mathrm{MOH}$, the medical specialists and assistant medical officers (AMO) tend to be more satisfied than other job designations. The medical specialists are significantly more satisfied than all the other job designations except for assistant medical officer (AMO). The assistant medical officers are significantly more satisfied than all the other job designations except for the medical specialist. The data also indicates high level of dissatisfaction between the pharmacists and some job designations as indicated by the large mean difference between pharmacists and medical specialists (mean difference -0.21); and pharmacists and assistant medical officers (mean difference -0.21).

\section{DISCUSSIONS}

There was found to be a good level of job satisfaction among $\mathrm{MOH}$ employees (overall satisfaction mean 3.45). However, opportunities for training were somewhat limited, (mean 2.98), although training received was found to be effective (mean 4.00). Heavy workload and poor recognition were also found to be not as satisfactory (mean 3.03) as other dimensions of job satisfaction. The medical specialists and assistant medical officers were found to be significantly more satisfied with their work than employees of other designations. However, although the medical specialists have a high level of job satisfaction, they also form the group with a high level of turnover intention. This indicates that job satisfaction is not necessarily the issue which causes the employee turnover. Rather, as observed by Rasiah, Abdullah and Tumin, ${ }^{13}$ aggressive expansion of private healthcare services following the Government's privatisation policy and recent development in medical tourism led to a further outflow of health professionals from the public to the private establishments. Such being the case, rather than job dissatisfaction, which led to employee turnover, it is actually higher demand, which causes employee turnover among the medical specialists.
Apart from medical specialists, almost $40 \%$ of the pharmacists also indicated their intention to resign; and the finding also indicates that more than half of the pharmacists $(50.8 \%$ ) have received job offers from private sector. Apart from pharmacists, dentists also have a high turnover intention (39.8\%) and a high proportion of dentists have also received job offers from private sector $(44.8 \%)$. A critical finding here is that unlike the medical specialists who have a high level of job satisfaction, the pharmacists and dentists were found to be less satisfied in comparison to other job designations. Therefore, the push factor may be stronger in these groups of employees.

\section{CONCLUSION}

Employee turnover among the public sector may not necessarily be due to job dissatisfaction. Demand from the private sector may also be an influencing factor. However, job dissatisfaction should not be dismissed altogether.

Disclosure on Conflict of Interest

The authors declared no potential conflict of interest with respect to the authorship and/or publication of this article.

\section{ACKNOWLEDGEMENT}

We would like to thank all employees of Institute of Health Management who have contributed both directly and/or indirectly to the successful completion of the research. 


\section{REFERENCES}

1. Stone RJ. Managing Human Resources: An Asian Perspective. Australia: John Wiley and Sons, 2009.

2. Park JS, Kim TH. Do types of organisational culture matter in nurse job satisfaction and turn over intention? Leadership in Health Services 2009; 22:20-38.

3. Ozaki M, Bito S, Matsumara S. Developing a Japanese hospital physician satisfaction scale. Int J Health Care Qual Assur 2008; 21:517-28.

4. Randhawa G. Relationship between job satisfac tion and turnover intentions: An empirical analy sis. Indian Management Studies Journal 2007; 11:149-59.

5. Sellgran G, Ekvall G, Tomson G. Nursing staff turnover: does leadership matter? Leadership in Health Services 2007; 20;169-83.

6. Locke, EA. The nature and causes of job satisfaction. In: Dunnette MP, ed. Handbook of Industrial and Organisational Psychology. Chicago: Rand McNally, 1976:1297-1350.

7. Stamps PL, Slaritt DB. Measurement of work satisfaction among health professionals. Med Care 1978; 16:337-50.

8. Rad AMM, De Moraes A. Factors affecting em ployees' job satisfaction in public hospitals. Journal of General Management 2009; 34:51-66.

9. Manaf NHA. Patient satisfaction in outpatient clinics of Malaysian public hospitals. IIUM Journal of Economics and Management 2006; 14:81-110.

10. Van Dam K. Time frames for leaving; An explor ative study of employees' intentions to leave the organisation in the future. Career Develop ment International 2008; 13:560-71.

11. Nunnally JC, Bernstein IH. Psychometric Theory. New York: McGraw-Hill, 1994.

12. Hair JF, Anderson RE, Tatham RL, Black WC. Multivariate Data Analysis. 5th Ed. New Jersey: Prentice Hall, 1998.

13. Rasiah R, Abdullah NRW, Tumin M. Markets and healthcare services in Malaysia: Critical issues. International Journal of Institutions and Economies 2011; 3:467-86. 